\title{
First molecular detection of Canine Hemoplasmas in Sivas province in central part of Turkey
}

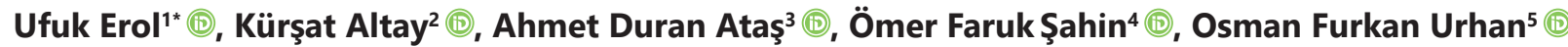 \\ 1,2,4 Department of Parasitology, Faculty of Veterinary Medicine, University of Sivas Cumhuriyet, Sivas, Turkey. \\ ${ }^{3}$ Department of Parasitology, Faculty of Medicine, University of Sivas Cumhuriyet, Sivas, Turkey. \\ ${ }^{5}$ Et ve Süt Kurumu, Sivas Et Kombinası Müdürlüğ̈̈, Sivas, Turkey.
}

Geliş Tarihi / Received: 25.03.2021, Kabul Tarihi / Accepted: 07.06.2021

\begin{abstract}
Canine hemoplasmas are vector-borne bacterial pathogens having worldwide distribution. There are two hemoplasmas species that cause disease in dogs. These are Mycoplasma haemocanis and Candidatus Mycoplasma haematoparvum. The aim of this study was to evaluate the prevalence of canine hemoplasmas among apparently healthy 194 owned-dogs in Sivas Province using species-specific polymerase chain reaction (PCR). According to our results, the overall prevalence of canine hemoplasmas was $14.94 \%(29 / 194)$. The molecular prevalence of $M$. haemocanis and $\mathrm{Ca}$. M. haematoparvum was detected as $8.24 \%(16 / 194)$ and $10.82 \%(21 / 194)$ respectively while the prevalence of co-infections was $4.12 \%$ (8/194). In this study, Ca. M. haematoparvum which can infect humans was found more prevalent than M. haemocanis. To the best of our knowledge, it is the first molecular study on the determination of canine hemoplasmas in Sivas province in Turkey.
\end{abstract}

Keywords: Canine hemoplasmas, Dog, PCR, Sivas, Turkey.

\section{Sivas ilinde Canine Hemoplasma'nin ilk moleküler tespiti}

\begin{abstract}
Özet: Canine hemoplasmas türleri vektör kaynaklı önemli bakteriyel patojenlerdendir. Etkenler dünyanın farklı bölgelerinde evcil köpeklerde tespit edilmiştir. Köpeklerde hastalığa neden olan iki önemli hemoplasma türü vardır. Bunlar sırasıyla Mycoplasma haemocanis ve Candidatus Mycoplasma haematoparvum'dur. Bu çalışmanın amacı Sivas ilinde 194 evcil köpekte canine hemoplasmas etkenlerinin yaygınlığının Polimeraz Zincir Reaksiyonu ile araştırılmasıdır. Bu çalışmada köpeklerin \%14,94 (29/194)'ünde en az bir canine hemoplasmas türü ile enfekte olduğu tespit edilmiştir. Köpeklerin \%8,24 (16/194)'ünde M. haemocanis, \%10,82 (21/194)'ünde ise Ca. M. haematoparvum tespit edilmiştir. Köpeklerin \%4,12 (8/194)'ünde ise miks enfeksiyon görülmüştür. Çalışmada köpeklerde Ca. M. haematoparvum'un M. haemocanis'e göre daha yaygın olduğu tespit edilmiştir. Bu çalışma ile bildiğimiz kadarıyla Sivas ilinde ilk kez köpeklerde moleküler yöntemlerle canine hemoplasmas türlerinin yaygınlığı araştırılmıştır.
\end{abstract}

Anahtar kelimeler: Canine hemoplasmas, Köpek, PCR, Sivas, Türkiye.

\section{Introduction}

Hemotrophic mycoplasmas (hemoplasmas) are tiny and pleomorphic bacterial agents that are cellwall-deficient, obligate, and gram-negative. These pathogens invade red blood cells (RBCs) of different vertebrates, including dogs (Messick 2004; Chalker 2005; Sykes et al. 2005). Two hemoplasmas species are determined as canine-specific. These species are Mycoplasma haemocanis and Candidatus Mycoplasma haematoparvum (Messick 2004; Sykes et al. 2005). Although these species might affect different organs and tissues, infections are mostly asymptomatic in healthy dogs (Messick 2004; Chalker 2005). In some cases, progressive anemia can be seen in acute infections in immunecompromised or splenectomized dogs (Messick 2004; Sykes et al. 2005). Canine hemoplasmas rarely cause death (Messick 2004; Chalker 2005).

Transmission of canine hemoplasmas species is still not well defined, however Rhipicephalus sanguineus, brown dog tick, is thought to be a possible vector species of these species (Messick 2004; Baker and Tasker 2016; Aktas and Ozubek 2017). M. haemocanis and Ca. M. haematoparvum may also be transmitted mechanically via blood transfusions, fresh blood-contaminated fomites, and blood-sucking arthropods (Messick 2004; Willi et al. 2010; Baker and Tasker 2016).

Yazışma adresi / Correspondence: Ufuk Erol, Department of Parasitology, Faculty of Veterinary Medicine, University of Sivas Cumhuriyet, Sivas, Turkey E-mail: ufukerol@cumhuriyet.edu.tr 
Microscopic, serological, and molecular methods have been used for the diagnosis of canine hemoplasmas infection so far (Messick 2004; Baker and Tasker 2016; Aktas and Ozubek 2018; Altay et al. 2020a). The microscopic techniques are successfully used for the diagnosis of clinical canine hemoplasmas infection (Baker and Tasker 2016) however, these techniques are not usable for the determination of chronic infections and may also cause false-positive results due to stain precipitation, basophilic stippling, or Howell-Jolly bodies (Kemming et al. 2004; Baker and Tasker 2016). Serological techniques and microscopic techniques are not fit to determine the pathogen species that cause canine hemoplasmas infection (Baker and Tasker 2016). Molecular identification techniques have been more preferred for the diagnosis of canine hemoplasmas compared to the microscopic and serological techniques. These methods; i) can determine the hemoplasmas species that caused infections in dogs ii) may find a small amount of nucleic acid that belongs to pathogens iii) can detect carrier animals (Messick 2004; Willi et al. 2010; Baker and Tasker 2016; Aktas and Ozubek 2017; Altay et al. 2020a).

Canine hemoplasmas species have been identified in different countries (Wengi et al. 2008; Compton et al. 2012; Baker and Tasker 2016; Maggi and Krämer 2019; Altay et al. 2020a), and in different parts of Turkey (Guo et al. 2017; Aktas and Ozubek 2017; Aktas and Ozubek 2018). There is a paucity of information on canine hemoplasmas in Sivas province. Due to this, the present study aimed to determine the molecular prevalence of canine hemoplasmas in Sivas province.

\section{Material and Methods}

\section{Study Area and Material}

Sivas province is placed in the central part of Turkey. Sivas has an approximately $28,400 \mathrm{~km}^{2}$ geographical area. The average annual temperature is $8.9^{\circ} \mathrm{C}$, the average precipitation, and relative humidity are 432 $\mathrm{mm}$ and $65 \%$ in Sivas, respectively.
The study material was composed of 194 (95 female, 99 male) apparently healthy owned-dog in four different parts of Sivas (Sivas City Center, Kangal, Yıldızeli, Hafik). The age, gender, and location data of the dogs were recorded. The blood samples were taken into blood collection tubes containing Etilendiamin tetraacetic acid (EDTA). The blood samples were stored at $-20^{\circ} \mathrm{C}$ until DNA extraction.

\section{Total Genomic DNA isolation and Polymerase Chain Reaction (PCR)}

Total genomic DNA was obtained from $200 \mu \mathrm{L}$ blood samples using PureLink Genomic DNA kit (Cat. No.: K1820-02, Invitrogen, Carlsbad, USA) according to the manufacturer's instructions. The genomic DNA samples were stored at $-20^{\circ} \mathrm{C}$ until use.

PCR assay using species-specific primers was performed for determination of the presence and distribution of canine Mycoplasma species (Torkan ve ark. 2014). Further information on primers was detailed in Table 1. PCR was performed in a final volume of $50 \mu \mathrm{L}$ including DNase-RNase-free sterile water (Cat No.: 129114, Qiagen ${ }^{\circledR}$, Germany), 10× PCR buffer (Thermo Scientific ${ }^{\text {TM }}$, Lithuanian), $2.5 \mathrm{mM}$ $\mathrm{MgCl}_{2}$ (25 mM) (Thermo Scientific ${ }^{\mathrm{TM}}$, Lithuanian), $200 \mu \mathrm{M}$ of each dNTP (Cat. No.: PCCSKU1019, Procomcure Biotech $\mathrm{GmbH}$ ), $1.25 \mathrm{U}$ of Taq DNA polymerase (Cat. No.: EP0402, Thermo Scientific ${ }^{\mathrm{TM}}$, Lithuanian), $2 \mu \mathrm{L}(10 \mathrm{pmol} / \mu \mathrm{L}$ ) of each of the primers, and $5 \mu \mathrm{L}$ template DNA. The PCR cycling conditions were done as described by Altay et al. (2020a). DNase-RNase-free sterile water (Cat. No.: 129114, Qiagen ${ }^{\circledR}$, Germany) was used as negative control, the genomic DNA of $M$. haemocanis isolate (accession number: MK015018, Altay et al. 2020a) and $\mathrm{Ca}$. M. haematoparvum (accession number: MK026012, Altay et al. 2020a) were used as positive controls for each PCR assay. Ten microliters of PCR products were electrophoresed on $1.5 \%$ agarose gel stained (100V, $45 \mathrm{~min})$ with ethidium bromide and then were visualized by UV transilluminator (Figure 1). DNA extraction and PCR assay were conducted in different rooms for prevention of cross-contamination.

Table 1. Primers using in the present study.

\begin{tabular}{|c|c|c|c|c|}
\hline Species & Primers 5' $\rightarrow 3^{\prime}$ & Target Gene & Length of Product & Reference \\
\hline \multirow{2}{*}{ M. haemocanis } & Forward GAAACTAAGGCCATAAATGACGC & \multirow{2}{*}{$16 \mathrm{~S}$ rRNA } & \multirow{2}{*}{$309 \mathrm{bp}$} & \multirow{2}{*}{ Torkan et al. 2014} \\
\hline & Reverse ACCTGTCACCTCGATAACCTCTAC & & & \\
\hline \multirow{2}{*}{ Ca. M. haematoparvum } & Forward ACGAAAGTCTGATGGAGCAATAC & \multirow{2}{*}{$16 \mathrm{~S}$ rRNA } & \multirow{2}{*}{$328 \mathrm{bp}$} & \multirow{2}{*}{ Torkan et al. 2014} \\
\hline & Reverse TATCTACGCATTCCACCGCTAC & & & \\
\hline
\end{tabular}


Statistical evaluation: Statistical analyses among various parameters were performed using the chisquare test. Differences were considered statistically significant if $p<0.05$.

\section{Results}

All dog blood samples were screened for $M$. haemocanis and $\mathrm{Ca}$. M. haematoparvum by PCR using the primers detailed in Table 1. The overall prevalence of hemoplasmas species was found to be $14.94 \%$ (29/194). The prevalence of $M$. haemocanis was detected as $8.24 \%(16 / 194)$, while the prevalence of $\mathrm{Ca}$. M. haematoparvum was detected as $10.82 \%$ $(21 / 194)$. Co-infections were found to be $4.12 \%$ (8/194) (Table 2).
The prevalence among female dogs was detected as $14.73 \%$ (14/95), while among the male dogs it was $15.15 \%$ (15/99). Canine hemoplasmas were found to be $8.95 \%(6 / 67)$ between 0 and 2 years of age, $19.40 \%(13 / 67)$ between 3 and 4 years of age, and $16.66 \%(10 / 60)$ in dogs $\geq 5$ years old (Table 2). The distribution of canine hemoplasmas in the sampling area was determined to be $18.84 \%$ $(13 / 69)$ in Sivas city center, $13.33 \%(6 / 45)$ in Kangal, $11.11 \%$ (5/45) in Hafik, and 14.28\% (5/35) in Yildizeli.

There were not statistically significant differences $(p<0.05)$ between the prevalence of hemoplasmas species, sampling area, gender, and age groups.

Table 2. Comparison of canine hemoplasmas among gender, sampling area, and age groups.

\begin{tabular}{|c|c|c|c|c|c|c|c|c|c|}
\hline \multirow{2}{*}{$\begin{array}{l}\text { Canine hemoplasmas } \\
\text { species }\end{array}$} & \multicolumn{2}{|c|}{ Gender } & \multicolumn{4}{|c|}{ Sampling Area } & \multicolumn{3}{|c|}{ Age groups } \\
\hline & Male & Female & Sivas City Canter & Hafik & Yıldızeli & Kangal & $0-2$ & $3-4$ & $\geq 5$ \\
\hline M. haemocanis & 3 & 5 & 6 & - & - & 2 & 4 & 2 & 2 \\
\hline Ca. M. haematoparvum & 8 & 5 & 3 & 3 & 4 & 3 & - & 7 & 6 \\
\hline Co-infections & 4 & 4 & 4 & 2 & 1 & 1 & 2 & 4 & 2 \\
\hline Total & $\begin{array}{c}15 \\
(15.15 \%) \\
\end{array}$ & $\begin{array}{c}14 \\
(14.73 \%) \\
\end{array}$ & $\begin{array}{c}13 \\
(18.84 \%)\end{array}$ & $\begin{array}{c}5 \\
(11.11 \%) \\
\end{array}$ & $\begin{array}{c}5 \\
(14.28 \%) \\
\end{array}$ & $\begin{array}{c}6 \\
(13.33 \%) \\
\end{array}$ & $\begin{array}{c}6 \\
(8.95 \%)\end{array}$ & $\begin{array}{c}13 \\
(19.40 \%) \\
\end{array}$ & $\begin{array}{c}10 \\
(16.66 \%)\end{array}$ \\
\hline p-value & \multicolumn{2}{|c|}{$p>0.05$} & \multicolumn{4}{|c|}{$p>0.05$} & \multicolumn{3}{|c|}{$p>0.05$} \\
\hline
\end{tabular}
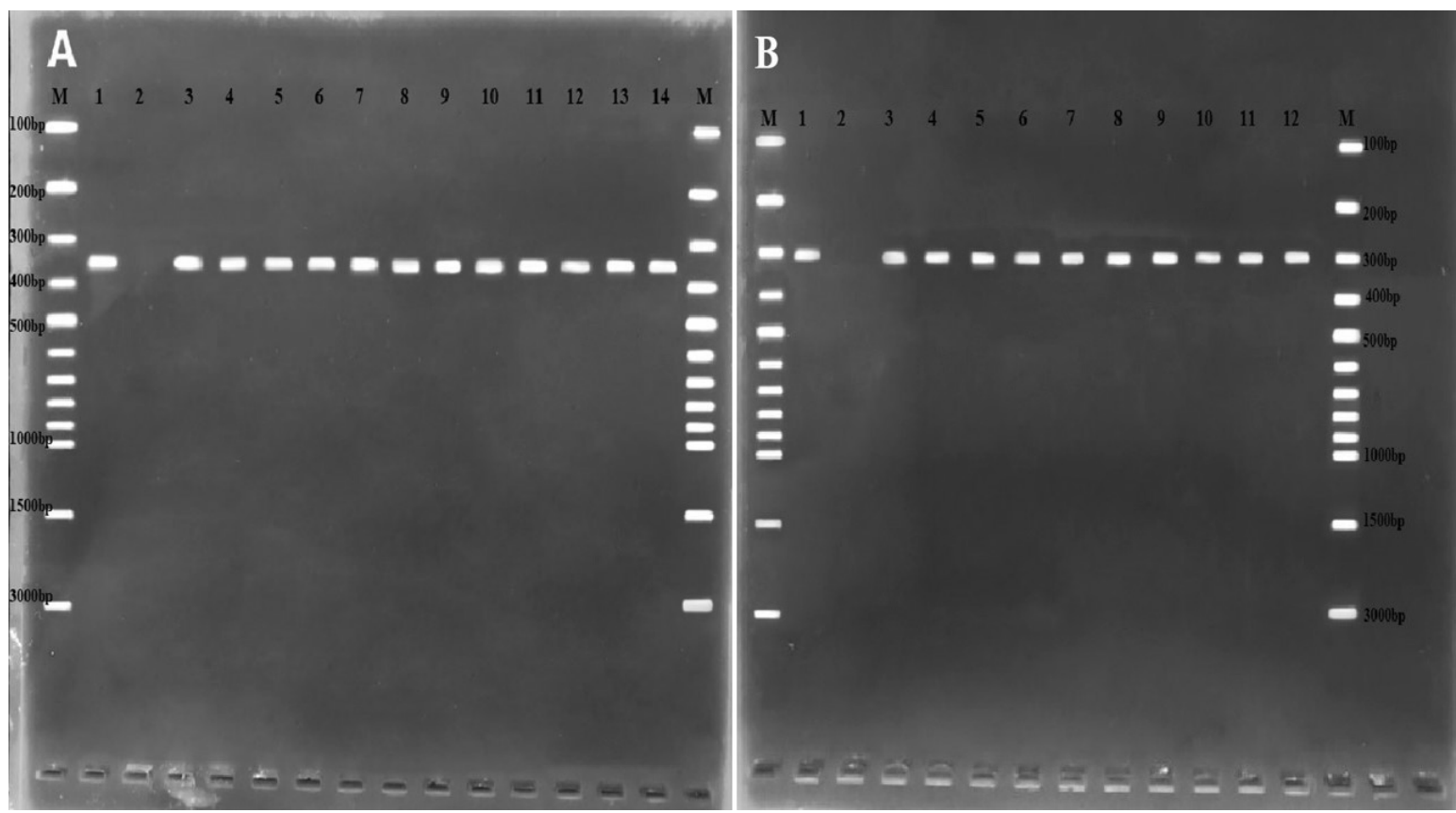

Figure 1. Agarose-gel electrophoresis of $C a$. M. haematoparvum (A) and M. haemocanis (B) specific polymerase chain reaction. M. Marker, Lane A1. Ca. M. haematoparvum positive control DNA from dog, Lane A2. negative control distilled water, Lane A3-A14. Ca. M. haematoparvum positive dog blood samples, Lane B1. M. haemocanis positive control DNA dog, Lane B2. negative control distilled water, Lane B3-B12. M. haemocanis positive dog blood samples. 


\section{Discussion and Conclusions}

Canine hemoplasmas are one of important tickborne pathogens. Two hemoplasmas species, $M$. haemocanis and Ca. M. haematoparvum, are known to be the pathogens for domestic and wild canine species (Messick 2004; Sykes et al. 2004; André et al. 2011; Torkan et al. 2014; Baker and Tasker 2016). M. haemocanis was reported for the first time in 1928, while Ca. M. haematoparvum was identified in 2004 (Sykes et al. 2004). M. haemocanis and Ca. $\mathrm{M}$. haematoparvum have a worldwide distribution (Wengi et al. 2008; Novacco et al. 2010; Compton et al. 2012; Baker and Tasker 2016; Maggi and Krämer 2019; Altay et al. 2020a), however there is little data available on the prevalence of these pathogens in Turkey (Guo et al. 2017; Aktas and Ozubek 2017; Aktas and Ozubek 2018). Sivas is the second-largest province and located in the central part of Turkey. There are found blood parasites such as Theileria, Babesia, Anaplasma, and Dirofilaria immitis in animal species like dogs, sheep, and cattle in different studies (Altay et al. 2017; Atas et al. 2018; Altay et al. 2020b). However, there is a lack of information molecular prevalence of canine hemoplasmas. Therefore, this study aimed to determine the prevalence of canine hemoplasmas in Sivas province using PCR.

There are different techniques to diagnose canine hemoplasmas species, but molecular identification techniques have been more preferred since they are faster and more specific than other identification techniques (Messick 2004; Willi et al. 2010; Torkan et al. 2014; Baker and Tasker 2016). M. haemocanis and $\mathrm{Ca}$. M. haematoparvum have been detected in different geographical areas such as Turkey, Italy, Spain, Portugal, the USA, Sudan, and Kyrgyzstan using species-specific PCR (Inokuma et al. 2006; Novacco et al. 2010; Compton et al. 2012; Aquino et al. 2016; Aktas and Ozubek 2017; Guo et al. 2017; Ravagnan et al. 2017; Aktas and Ozubek 2018; Altay et al. 2020a). A few studies were carried out to determine the presence and distribution of canine hemoplasma infection in Turkey (Aktas and Ozubek 2017; Guo et al. 2017; Aktas and Ozubek 2018). These studies revealed that the prevalence of canine hemoplasmas was ranging from 15.3 to $38.3 \%$ in dog population in different parts of Turkey (Aktas and Ozubek 2017; Guo et al. 2017; Aktas and Ozubek 2018). In the present study, the overall prevalence was determined as $14.94 \%$ (29/194). Our result was similar to that of Aktas and Ozubek (2018) $(15.3 \%)$, however the prevalence we found was lower than that in Konya \%23.95\% (Guo et al. 2017) and in Diyarbakır 38.3\% (Aktas and Ozubek 2017). Like other vector-borne diseases, the prevalence of canine hemoplasmas might change depending on climate conditions in sampling areas, presence and distribution of vector species, and dog origin (stray or owned) (Baker and Tasker 2016; Guo et al. 2017; Aktas and Ozubek 2018; Maggi and Krämer 2019). The present study was performed using owneddogs while the studies that have higher prevalence of canine hemoplasmas in Konya (Guo et al. 2017) and in Diyarbakır (Aktas and Ozubek 2017) were conducted using stray dog samples. Stray dogs are frequently exposed to ectoparasites such as ticks and fleas. Therefore, vector-borne pathogens may be more prevalent in stray dogs compared to owned-dogs. For this reason, we speculate that the lower prevalence $(14.94 \%)$ compared to the ones in Diyarbakır (38.3\%) and Konya (23.95\%) could be related to that this study was performed using owned-dog blood samples.

In the present study, there were no statistically significant differences between the prevalence of $\mathrm{M}$. haemocanis and $\mathrm{Ca}$. M. haematoparvum. The prevalence of $M$. haemocanis was detected as $8.24 \%(16 / 194)$, while the prevalence of $\mathrm{Ca}$. M. haematoparvum was found to be $10.82 \%(21 / 194)$. In the previous studies conducted in Turkey, $M$. haemocanis was found more prevalent than $\mathrm{Ca}$. M. haematoparvum (Aktas and Ozubek 2017; Aktas and Ozubek 2018), however, in this study, Ca. M. haematoparvum was found more prevalent than M. haemocanis. These findings were similar to the studies in France (Kenny et al. 2004), Sudan (Inokuma et al. 2006), and the USA (Compton et al. 2012). Furthermore, Ca. M. haematoparvum can cause human infections (Maggi et al. 2013). Therefore, veterinarians and people who have intimate contact with dogs should be careful about this pathogen to protect their health.

According to our PCR results, the prevalence of canine hemoplasmas was found to be $15.15 \%$ $(15 / 99)$ in the male dogs and $14.73 \%(14 / 95)$ in the female dogs. There was no significant association of canine hemoplasma infection with dog gender. This result was similar to the studies performed in different countries like France (Kenny et al. 2004), Italy (Ravagnan et al. 2017), and Turkey (Aktas and Ozubek 2017; Aktas and Ozubek 2018). In the present study, we found that the prevalence of canine hemoplasmas in the male dogs was slightly higher than in the female dogs. This finding may be related to that male dogs tend to have more aggressive contact with other dogs than female dogs, due to 
these pathogens also can be transmitted with fresh blood (Sasaki et al. 2008; Barker et al. 2010).

Canine hemoplasmas were found in all age groups (Table 2). There was not found statistically significant differences between the prevalence of different age groups in the present study. This result was compatible with the studies conducted in different countries like Switzerland (Wengi et al. 2008), Italy (Ravagnan et al. 2017), Turkey (Aktas and Ozubek 2017; Aktas and Ozubek 2018), and the USA (Compton et al., 2012). Furthermore, our results revealed that the prevalence of canine hemoplasmas was more prevalent among the older age groups (3-4 years and $\geq 5$ years) than younger age group ( 0 -2 years) (Table 2 ). This finding could be attributed to that older animals are more exposed to ectoparasites (ticks or fleas) compared to the younger ones. Due to this, we thought that vector-borne pathogens like canine hemoplasmas are more prevalent in older animals. Normally, canine hemoplasmas should be more prevalent in $\geq 5$ years' dogs than 3-4 years, but these pathogens were found more prevalent in 3-4 years' dogs (Table 2). This result could be related to the successful tick control by owners of these dogs that are older than 5 years old.

Mycoplasma haemocanis and Ca. M. haematoparvum were found in all sampling areas; Sivas city canter, Kangal, Hafik, and Yıldızeli, and the prevalences were $18.84 \%, 13.33 \%, 11.11 \%$, and $14.28 \%$, respectively. The difference between the sampling areas was not statistically significant. This result could be related to that the climate conditions of all sampling areas are similar. The climate conditions in geographical areas can directly affect distribution and abundance of vector species, and hence the prevalence of pathogens, especially vector-borne pathogens (Wengi et al. 2008; Novacco et al. 2010; Maggi and Krämer 2019). Probably because of that, we did not find statistically significant differences between the sampling areas.

In conclusion, vector-borne diseases (VBDs) are the main health problem in the world and are threat to both animal and human health. M. haemocanis and $\mathrm{Ca}$. M. haematoparvum are one of important vector-borne diseases for dog populations. Moreover, these species also infect humans (Maggi et al. 2013). For this reason, determination of these pathogens in dog populations is vital to protect both animal and human health. To better understand the prevalence and the presence of $M$. haemocanis and $\mathrm{Ca}$. M. haematoparvum in Sivas, there need to be more comprehensive surveys, including domestic and wild canine species.

Ethic statement: Permission was obtained from the Sivas Cumhuriyet University Animal Experiments Local Ethics Committee (Approval number: 16.03.2021-513).

Acknowledgments: The authors thank Dr. Mehmet Fatih AYDIN (Department of Public Health, Faculty of Health Sciences, University of Karamanoglu Mehmetbey, Turkey) for providing positive control DNA's of Mycoplasma haemocanis and Candidatus Mycoplasma haematoparvum and also, we are grateful to Veterinarians Anıl Berat Mutlu, Enes KARAKAYA, and Eren ÇAMDALI for their kind help during sample collection.

Conflict of Interest: The authors declare that they have no conflicts.

\section{References}

Aktas M, Ozubek S. (2017) Molecular survey of haemoplasmas in shelter dogs and associations with Rhipicephalus sanguineus sensu lato. Med Vet Entomol. 31(4), 457-461. doi: 10.1111/ mve.12244.

Aktas M, Ozubek S. (2018) A molecular survey of hemoplasmas in domestic dogs from Turkey. Vet Microbiol. 221, 94-97. doi: 10.1016/j.vetmic.2018.06.004.

Altay K, Aydın MF, Aytmirzakizi A, Jumakanova Z, Cunusova A Dumanlı, N. (2020a) First molecular evidence for Mycoplasma haemocanis and Candidatus Mycoplasma haematoparvum in asymptomatic shelter dogs in Kyrgyzstan. Kafkas Univ Vet Fak Derg. 26(1), 143-146. doi: 10.9775/kvfd.2019.22196

Altay K, Atas AD, Ograk YZ, Ozkan E. (2020b) Survey of Theileria, Babesia and Anaplasma Infections of Cattle and Ticks from Sivas Region of Turkey. Erciyes Üniv Vet Fak Derg. 17(1), 32 38. doi: 10.32707/ercivet.690618

Altay K, Atas AD, Ozkan E. (2017) Molecular Survey of Theileria and Babesia Species in Small Ruminants and Ticks from Sivas Region of Turkey. Manas J Agricul Vet Life Sci. 7(1), 30-39.

André MR, Adania CH, Allegretti SM, Machado RZ. (2011) Hemoplasmas in wild canids and felids in Brazil. J Zoo Wild Med. 42(2), 342-347. doi: 10.1638/2010-0198.1.

Aquino LC, Kamani J, Haruna AM, Paludo GR, Hicks CA, Helps CR, Tasker S. (2016) Analysis of risk factors and prevalence of haemoplasma infection in dogs. Vet Parasitol. 221, 111-117. doi: 10.1016/j.vetpar.2016.03.014.

Atas AD, Altay K, Alim A, Ozkan, E. (2018) Survey of Dirofilaria immitis in dogs from Sivas Province in the Central Anatolia Region of Turkey. Turk J Vet Anim Sci. 42(2), 130-134. doi:10.3906/vet-1707-93.

Baker E, Tasker S. (2016) Haemoplasmosis. In: Day, M.J. (Ed.): Arthropod-borne infectious diseases of the dog and cat. CRC Press, New York, pp.97-107.

Barker EN, Tasker S, Day MJ, Warman SM, Woolley K, Birtles R, Georges KC, Ezeokoli CD, Newaj-Fyzul A, Campbell MD, Sparagano OA, Cleaveland S, Helps CR. (2010) Development and use of real-time PCR to detect and quantify Mycoplasma haemocanis and Candidatus Mycoplasma haematoparvum 
in dogs. Vet Microbiol. 140, 167-170. doi: 10.1016/j. vetmic.2009.07.006.

Chalker VJ. (2005) Canine mycoplasmas. Res Vet Sci. 79(1), 1-8. doi: 10.1016/j.rvsc.2004.10.002.

Compton SM, Maggi RG, Breitschwerdt EB. (2012) Candidatus Mycoplasma haematoparvum and Mycoplasma haemocanis infections in dogs from the United States. Comp Immunol Microbiol Infect Dis. 35(6), 557-562. doi: 10.1016/j. cimid.2012.06.004

Guo H, Sevinc F, Ceylan O, Sevinc M, Ince E, Gao Y, Moumouni PFA, Liu M, Efstratiou A, Wang G, Cao S, Zhou M, Jirapattharasate C, Ringo AE, Zhenh W, Xuan X. (2017) A PCR survey of vector-borne pathogens in different dog populations from Turkey. Acta Parasitol. 62(3) 533-540. doi: 10.1515/ap-20170064.

Inokuma $\mathrm{H}$, Oyamada $\mathrm{M}$, Davoust $\mathrm{B}$, Boni $\mathrm{M}$, Dereure J, Bucheton B, Hammad A, Watanabe M, Itamoto K, Okuda M, Brouqui P. (2006) Epidemiological survey of Ehrlichia canis and related species infection in dogs in eastern Sudan. Ann NY Acad Sci. 1078, 461-463. doi: 10.1196/annals.1374.085.

Kenny MJ, Shaw SE, Beugnet F, Tasker S. (2004) Demonstration of two distinct hemotropic mycoplasmas in French dogs. J Clin Microbiol. 42(11), 5397-5399. doi: 10.1128/JCM.42.11.53975399.2004.

Maggi RG, Krämer F. (2019) A review on the occurrence of companion vector-borne diseases in pet animals in Latin America. Parasit Vectors. 12(1), 1-37. doi: 10.1186/s13071019-3407-x

Maggi RG, Mascarelli PE, Havenga LN, Naidoo V, Breitschwerdt EB. (2013) Co-infection with Anaplasma platys, Bartonella henselae and Candidatus Mycoplasma haematoparvum in a veterinarian. Parasit Vectors. 6(1), 1-10. doi: 10.1186/17563305-6-103.

Messick JB. (2004) Hemotrophic mycoplasmas (hemoplasmas): a review and new insights into pathogenic potential. Vet Clin Pathol. 33(1), 2-13. doi: 10.1111/j.1939-165x.2004.tb00342.x.

Novacco M, Meli ML, Gentilini F, Marsilio F, Ceci C, Pennisi MG, Lombardo G, Lloret A, Santos L, Carrapic T, Willi B, Wolf G, Lutz H, Hofmann-Lehmann, R. (2010) Prevalence and geographical distribution of canine hemotropic mycoplasma infections in Mediterranean countries and analysis of risk factors for infection. Vet Microbiol. 142(3-4), 276-284. doi: 10.1016/j.vetmic.2009.09.069.

Ravagnan S, Carli E, Piseddu E, Da Rold G, Porcellato $E_{\imath}$ Zanardello C, Carminato A, Vascellari M, Capelli G. (2017) Prevalence and molecular characterization of canine and feline hemotropic mycoplasmas (hemoplasmas) in northern Italy. Parasit Vectors. 10(1), 132. doi: 10.1186/s13071-0172069-9.

Sasaki M, Ohta K, Matsuu A, Hirata H, Ikadai H, Oyamada T. (2008) A molecular survey of Mycoplasma haemocanis in dogs and foxes in Aomori Prefecture, Japan. J Protozool Res. 18(2), $57-$ 60. doi: 10.32268/jprotozoolres.18.2_57

Sykes JE, Bailiff NL, Ball LM, Foreman O, George JW, Fry MM. (2004) Identification of a novel hemotropic mycoplasma in a splenectomized dog with hemic neoplasia. J Am Vet Med Assoc. 224(12), 1946-1951. doi: 10.2460/javma.2004.224.1946.

Sykes JE, Ball LM, Bailiff NL, Fry MM. (2005) 'Candidatus Mycoplasma haematoparvum', a novel small haemotropic mycoplasma from a dog. Int J Syst Evol Microbiol. 55(1), 2730. doi: 10.1099/ijs.0.02989-0.

Torkan S, Aldavood SJ, Sekhavatmandi A, Moshkelani S. (2014) Detection of haemotropic Mycoplasma (Haemobartonella) using multiplex PCR and its relationship with epidemiological factors in dogs. Comp Clin Pathol. 23(3), 669-672. doi: 10.1007/s00580-012-1668-2.

Wengi N, Willi B, Boretti FS, Cattori V, Riond B, Meli ML, Reusch CE, Lutz H, Hofmann-Lehmann R. (2008) Realtime PCR-based prevalence study, infection follow-up and molecular characterization of canine hemotropic mycoplasmas. Vet Microbiol. 126(1-3), 132-141. doi: 10.1016/j.vetmic.2007.06.018.

Willi B, Novacco M, Meli ML, Wolf-Jäckel GA, Boretti FS, Wengi $\mathrm{N}$, Lutz H, Hofmann-Lehmann R. (2010) Haemotropic mycoplasmas of cats and dogs: transmission, diagnosis, prevalence and importance in Europe. Schweiz Arch Tierheilkd. 152(5), 237. doi: 10.1024/0036-7281/a000055. 